\title{
ALVAC-CEA Vaccine
}

National Cancer Institute

\section{Source}

National Cancer Institute. ALVAC-CEA Vaccine. NCI Thesaurus. Code C1648.

A cancer vaccine consisting of ALVAC, a highly attenuated poxvirus strain derived from the canarypox virus, encoding for the tumor associated antigen (TAA) carcinoembryonic antigen (CEA), with potential antineoplastic activity. Upon administration, ALVAC-CEA vaccine expresses CEA and may stimulate a host immune response ag ainst tumor cells expressing CEA. This may result in the inhibition of tumor growth and/or metastasis. CEA is overexpressed in a variety of tumor cell types. 